\title{
Morten Bøås
}

Forskningsprofessor

Norsk utenrikspolitisk institutt

\section{De glemte heltene}

\author{
De lokale legene og sykepleierne \\ som ble stående midt i ebolaepide- \\ mien og gjorde hva de kunne med \\ det lille de hadde, er våre glemte \\ helter. Vi kan hedre dem ved å bidra \\ tilå forbedre helsesystemeri svake \\ og sårbare stater. Da hjelper vi \\ samtidig oss selv.
}

Ebolautbruddet i Vest-Afrika er på retur. I Liberia har det ikke vært noen tilfeller siden juni. Siden mer enn en inkubasjonsperiode (42 dager) uten nye tilfeller har passert, regnes landet som smittefritt. I nabolandene Guinea og Sierra Leone er det fortsatt en viss spredning, men den er begrenset til noen få tilfeller langs grensen mellom de to landene.

Det er bra, men vi må huske at dette er det største utbruddet av ebola som vi kjenner til. Over 11000 mennesker er døde, og de sosiale og økonomiske kostnadene har satt de allerede svært fattige landene langt tilbake. Uten internasjonal innsats hadde man ikke klart å stoppe utbruddet, men samtidig er det heller ingen tvil om at sentrale organisasjoner som Verdens helseorganisasjon var altfor sent på banen.

Jeg har gjort feltarbeid i Liberia og Sierra Leone siden midt i 1990-årene og kjenner landene godt. Her har jeg venner og gode kolleger, men jeg vet også utmerket godt hvor svake disse to statene er. Jeg var i Liberia da utbruddet krysset grensen fra
Guinea og Sierra Leone. Grensene mellom disse landene er så porøse, avstandene så korte og befolkningene så mobile at det kun var snakk om tid før smitten måtte nå Liberia også. På tross av dette var lite eller ingenting gjort fra myndighetenes side. Systemet sviktet, men enkelte leger og sykepleiere hadde forberedt seg. Noen hadde kontakter i utlandet som de spurte til råds, andre skaffet seg noe kunnskap fra nettet og prøvde å samle sammen oppvaskhansker, plastbøtter, presenninger og gummistøvler. Alt som kunne brukes for å prøve å begrense smitte og å beskytte seg selv. Noen lyktes. En lege i en mindre provinshovedstad klarte ved slike enkle virkemidler å gjøre sitt lille sykehus om til en smittevernenhet som stort sett fungerte. Men altfor mange ble helt overmannet av situasjonen. Det ble raskt for mange pasienter til at de kunne unngå smittespredning - fra helsestasjon til helsestasjon og fra sykehus til sykehus.

Ofte var det ikke annet leger og sykepleiere kunne gjøre enn å gi en viss form for smertelindring og trøst til pasienter som ventet på å dø. Kanskje oppnådde de ikke så mye, og det ble helt sikkert også gjort mye galt, men poenget er at de aller fleste leger og sykepleiere ikke stakk av. De ble ved klinikkene sine selv om de ble sentrum for død og lidelse, og veldig mange av dem falt på post.

Det er trist om disse eksemplene på oppofrelse blir glemt, men like trist er det hvis vi glemmer at en viktig årsak til at epidemien fikk så stort omfang er at helsevese- net i disse landene er blitt fors $\varnothing \mathrm{mt}$ i årevis. Ja, dette er først og fremst et nasjonalt ansvar. Imidlertid er ikke dette bare noen av verdens fattigste stater, men to av dem, Liberia og Sierra Leone, har også vært gjenstand for store $\mathrm{FN}$-intervensjoner som har kostet massivt med penger. Det har ikke bedret situasjonen for de lokale sykehusene. Ifølge Verdensbanken har Liberia og Sierra Leone henholdsvis 4,2 millioner og 6 millioner innbyggere. Tall fra Verdens helseorganisasjon viser at Liberia $ø \varnothing r$ utbruddet hadde 51 leger og 978 sykepleiere, mens tilsvarende for Sierra Leone var 136 leger og 1017 sykepleiere. Hvor mange som nå er igjen, det vet jeg ikke. Jeg tror ikke noen helt har oversikten, men to ting er sikkert: De lokale legene og sykepleierne som ble stående mitt oppe i dette her og gjorde hva de kunne med det lille de hadde, er ebolaepidemiens glemte helter. En måte å hedre dem på samtidig som vi også faktisk beskytter oss selv, er å hjelpe til med å bygge mer robuste helsesystemer i svake og sårbare stater. Det kommer et nytt utbrudd, kanskje her, kanskje et annet sted. Det kan være ebola, det kan være en annen tilsvarende sykdom. Tenk på det neste gang noen ber om et bidrag eller du synes det sendes for mye penger ut av landet.

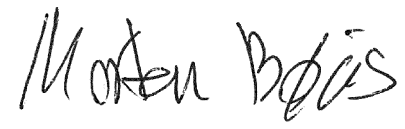

